\title{
2 JC Virus, Helicobacter pylori, and Oesophageal Achalasia: 3 Preliminary Results from a Retrospective Case-Control Study
}

4 Emanuele Sinagra $\cdot$ Elena Gallo $\cdot$ Filippo Mocciaro $\cdot$ Mario Stella $\cdot$

5 Giuseppe Malizia $\cdot$ Luigi Maria Montalbano $\cdot$ Ambrogio Orlando •

6 Gennaro D'Amico • Mario Cottone • Aroldo Gabriele Rizzo

Received: 26 July 2012/ Accepted: 1 November 2012

(C) Springer Science+Business Media New York 2012

To the Editor:

$\mathrm{JC}$ virus (JCV) is a member of the polyomavirus family. It infects humans worldwide, and $90 \%$ of the population carry antibodies to the virus by adult life [1]. The initial infection is asymptomatic, but it may become persistent. JCV DNA is frequently present in the upper and lower gastrointestinal tract of healthy adults [2, 3].

Several studies have suggested the involvement of certain DNA viruses in chronic gastrointestinal motility disorders such as chronic intestinal pseudo-obstruction [4-7]. Although a close causal relationship between neurotropic viruses and enteric neuromuscular lesion is not easily demonstrated, the identification of neurotropic viruses and/ or molecular components associated with them may help to clarify their role in the highly severe gastrointestinal disease.

Electronic supplementary material The online version of this article (doi:10.1007/s10620-012-2485-9) contains supplementary material, which is available to authorized users.

E. Sinagra $\cdot$ F. Mocciaro $\cdot$ A. Orlando $\cdot$ M. Cottone

DIBIMIS, Unit of Internal Medicine, Ospedali Riuniti "Villa

Sofia-Cervello", University of Palermo, via trabucco 180, 90136

Palermo, Italy

\section{E. Sinagra $(\bowtie)$}

via degli orti 41, 90143 Palermo, Italy

e-mail: manuelitomagico@ hotmail.it

\section{E. Gallo $\cdot$ M. Stella $\cdot$ A. G. Rizzo}

Unit of Pathology, Ospedali Riuniti "Villa Sofia-Cervello",

University of Palermo, via trabucco 180, 90136 Palermo, Italy

G. Malizia - L. M. Montalbano - G. D'Amico

Unit of Gastroenterology, Ospedali Riuniti "Villa Sofia-

Cervello", University of Palermo, via trabucco 180, 90136

Palermo, Italy
The aim of our study was to assess the prevalence of JC virus in a cohort of patients with oesophageal achalasia, comparing it with a cohort of healthy subjects, in order to evaluate whether JC virus could be play a role in this disease; we evaluated also the relationship between JC virus and Helicobacter pylori (HP).

In the cohort of patients with achalasia, 12 out of 15 $(80 \%)$ had a positive JC-PCR, while in the cohort of healthy controls, ten out of $15(66.7 \%)$ had a positive JC-PCR (chi-square 0.68 , odds ratio $2, p=0.409$ ). In the cohort of patients with achalasia, 13 out of $15(86.7 \%)$ had a positive hystologic HP test, while in the cohort of healthy controls, eight out of $15(53.3 \%)$ had a positive hystologic HP test. Curiously, in the entire cohort of patients, JC virus infection proved to be protective against HP infection (chisquare 11.35 , odds ratio $0.09, p=0.0008$ ). The prevalence of HP and JC virus infection in the entire cohort is shown in Table 1.

Because of the known neuropathic capability of JC virus, and its frequent presence in the upper gastrointestinal tract, as well as in the gut, we proposed that JCV might be detectable in tissues of patients with oesophageal achalasia, and possibly be involved in the pathogenesis of this disease. However, in this study the difference between the prevalence of JC virus in achalasia patients and in healthy controls was not statistically significant, probably due to the small number of cases and control subjects.

Few data are available about the relationship between JC virus and HP. Selgrad and coworkers, in their case-control study, showed that JC virus is present in HP induced gastritis and gastric cancer [9]. By contrast, the findings of our case-control study show that JC virus could be a protective factor against HP infection, though the biological and pathophysiological reasons for this microbiological interference are not yet known.

$\begin{array}{lll}\text { Journal : Large 10620 } & \text { Dispatch : } \mathbf{7 - 1 2 - 2 0 1 2} & \text { Pages : } \mathbf{2} \\ \text { Article No. : } \mathbf{2 4 8 5} & \square \text { LE } & \square \text { TYPESET } \\ \text { MS Code : } & \boldsymbol{\sim}_{\mathrm{CP}} & \boldsymbol{D I S K}_{\mathrm{DISK}}\end{array}$


60

61

62

63

64

65

66

67
Table 1 Distribution of JC virus and HP infection in the entire cohort of patients

\begin{tabular}{lll}
\hline Parameter & HP positive & HP negative \\
\hline JC virus positive & 5 & 15 \\
JC virus negative & 6 & 4 \\
\hline
\end{tabular}

HP Helicobacter pylori

\section{References}

1. Knowles WA. Discovery and epidemiology of the human polyomaviruses BK virus (BKV) and JC virus (JCV). Adv Exp Med Biol. 2006;577:19-45.

2. Laghi L, Randolph AE, Chauhan DP, et al. JC virus DNA is present in the mucosa of the human colon and in colorectal cancers. Proc Natl Acad Sci USA. 1999;96:7484-7489.

3. Ricciardiello L, Laghi L, Ramamirtham P, et al. JC virus DNA sequences are frequently present in the human upper and lower gastrointestinal tract. Gastroenterology. 2000;119:1228-1235.

In conclusion, despite the retrospective nature of our study and the small number of patients involved, we suggest that actually the basis to consider JC virus as an etiologic factor in pathogenesis of oesophageal achalasia is not significant. Curiously, JC virus could be a protective factor against HP infection, though the reasons of this antagonism are not fully elucidated. Further prospective case-control studies, with a larger number of patients, are needed to clarify the possible etiopathogenetic role of JC virus in oesophageal achalasia and the relationship between JC virus and HP.

The methods for the letter are available in supplementary material.
4. Debinski HS, Kamm MA, Talbot IC, Khan G, Kangro HO, Jeffries DJ. DNA viruses in the pathogenesis of sporadic chronic idiopathic intestinal pseudo-obstruction. Gut. 1997;41:100-106.

5. Press MF, Riddell RH, Ringus J. Cytomegalovirus inclusion disease. Its occurrence in the myenteric plexus of a renal transplant patient. Arch Pathol Lab Med. 1980;104:580-583.

6. Robertson CS, Martin BA, Atkinson M. Varicella-zoster virus DNA in the oesophageal myenteric plexus in achalasia. Gut. 1993;34:299-302.

7. Selgrad M, De Giorgio R, Fini L, et al. JC virus infects the enteric glia of patients with chronic idiopathic intestinal pseudo-obstruction. Gut. 2009;58:25-32.

8. Zheng H, Murai Y, Hong M, et al. JC [corrected] virus detection in human tissue specimens. J Clin Pathol. 2007;60:787-793.

9. Selgrad M, Wex T, Kuester D, et al. JC virus is present in $H$. pylori induced gastritis and gastric cancer. Gastroenterology. 2008;134: A-293.
75

76

77

78

79

80

81

82

83

84

85

86

87

88

89

90

91

92

93

94

95

96

97

98

99

100

101

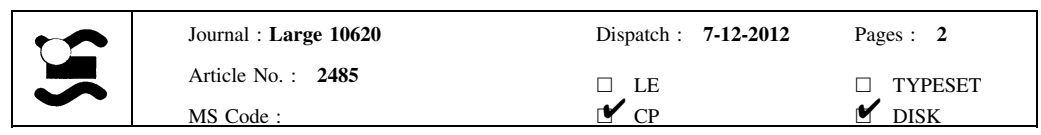

